\title{
The Dynamics of Organizing Institutions for the Resolution of Election Conflicts in Indonesia During 2005-2020 Period
}

\author{
Taufik Firmanto* \\ Law Study Program \\ STIH Bima \\ Bima, Indonesia \\ taufik@stihm-bima.ac.id \\ Muchamad Ali Safaat \\ Faculty of Law, Brawijaya University \\ Malang, Indonesia \\ sa Benefits@ub.ac.id
}

\author{
M Fadli \\ Faculty of Law, Brawijaya University \\ Malang, Indonesia \\ mfadlifh@ub.ac.id \\ I Istislam \\ Faculty of Law, Brawijaya University \\ Malang, Indonesia \\ istislam@ub.ac.id
}

\begin{abstract}
This article is the result of research on the dynamics of direct election conflict resolution institutions in Indonesia from 2005 to 2020 . This study examines regulations on Regional Head Election and law enforcement with a focus on the authority of the judiciary in resolving disputes over the results in Indonesia. The purpose of this research is to find the ideal model for a special Regional Head Election judiciary body in Indonesia. The method used in this research is a type of normative juridical research using legal materials, data, and several approaches commonly used in legal research, namely the statute approach, conceptual approach, case approach, and the historical comparative approach. The technique of collecting legal materials as data used in this study is library research using content analysis. Legal materials as data are then subjected to discussion, data analysis, and classification into certain groups to be analyzed into information. The results of this study conclude that the efforts to organize court institutions for dispute over the results of the Regional Election in Indonesia for the $2005-2020$ period are very dynamic. As a conclusion and suggestions, the author proposes two institutional options for the settlement of Regional Head Election disputes which are (a) Establishing a Special Judiciary Body within the Civil Court of Justice which is domiciled in each provincial capital to adjudicate and decide on election disputes, with other expanded powers in the form of adjudicating Regional Head Election crimes as well as examining and adjudicating election, regional election, administrative process, and election disputes; or (b) Defining the authority of the Constitutional Court to adjudicate disputes over the results of the Regional Head Election (in addition to the PHPU) without any differentiation between the General Election and the Regional Head Election.
\end{abstract}

Keywords-dynamics, settlement of disputes over results, regional head election

\section{INTRODUCTION}

Post-reform democratization in 1998 in Indonesia has resulted in a state administration system that is significantly different from the state structure of the New Order regime. This post-reformation was carried out in the direct Presidential Election in 2004, as well as inspiring direct Regional Head Elections (Indonesia: pilkada) since 2005.
Previously, the Regional Head Election was elected as a representative by the Regional House of Representative (DPRD).

Based on the constitution, the implementation of Regional Head Election is regulated in Article 18 paragraph (4), the 1945 Constitution of the Republic of Indonesia (UUD NRI) which states: "Governors, Regents and Mayors respectively as Head of Provincial, Regency and City Government are elected by democratic". Post-reform, by the legislators, the phrase "democratically elected" was translated into direct election by the people into Law Number 32 Year 2004. Direct Regional Head Election is also interpreted as a necessity in democratic life as a manifestation of sovereignty people [1].

As political contestants fighting for public office, the logical consequence of direct Regional Head Election is election disputes. The problems include administrative issues (process disputes), election crimes, and disputes over the results of vote acquisition. Of the three cases, the result dispute becomes a very crucial issue because it is the final point in determining who wins and losses, who will control the government leadership in the regions. Normatively, what is meant by disputes over election results according to Article 156 of Law Number 1 of 2015, namely:

"Election Result Disputes are disputes between the Provincial KPU and / or Regency / Municipal $K P U$ and election participants regarding the determination of the votes acquired by the Election results. A dispute over the determination of the acquisition of votes as a result of the Election is a dispute over the determination of the vote acquisition which is significant and can affect the determination of the candidate to advance to the next round or the determination of the elected candidate ".

Regarding the settlement of disputes over the results of the Regional Head Election, the government has recently passed the law Number 10 of 2016, where Article 157 paragraph (1) of this Law mandates "Election result dispute cases are examined and tried by a special judicial body". This special judicial body must be formed before the 
implementation of the national simultaneous election. However, for the time being, cases of dispute over votes resulting from the election are examined and tried by the Constitutional Court until a special judicial body is formed.

Of the four simultaneous regional elections in 2015-2020, a number of facts can be observed, including the number of simultaneous Regional Head Election cases that were tried by the Constitutional Court in 2015-2020. in full can be seen in the table as follows.

TABLE I. RECAPITULATION OF THE NUMBER OF SIMULTANEOUS ELECTION RESULT DISPUTES CASES TRIED BY THE CONSTITUTIONAL COURT 2015-2020

\begin{tabular}{|l|l|c|l|}
\hline No. & $\begin{array}{l}\text { Regional Head } \\
\text { Election Year }\end{array}$ & $\begin{array}{l}\text { Number of } \\
\text { Regions }\end{array}$ & $\begin{array}{l}\text { Number of } \\
\text { Cases }\end{array}$ \\
\hline 1. & 2015 & 269 & 152 cases \\
\hline 2. & 2017 & 101 & 60 cases \\
\hline 3. & 2018 & 171 & 71 cases \\
\hline 4. & 2020 & 270 & 136 cases \\
\hline
\end{tabular}

From the table, it can be seen that in terms of numbers, the disputes over the results of the simultaneous regional elections that were tried by the Constitutional Court were quite significant, in relation to the four simultaneous regional elections and the settlement of the disputes, it can be seen that from the 2015 simultaneous Regional Head Election held in 269 regions with the number of disputes entered. to the Constitutional Court as many as 152 cases from 137 regions. Then in 2017 regional elections were held simultaneously in 101 regions with the submission of disputes totaling 60 cases from 50 different regions. In the simultaneous Regional Head Election in 2018, there were simultaneous Regional Head Election in 171 regions with 71 cases of disputes submitted to the Constitutional Court from 58 regions [2]. Meanwhile, in the latest simultaneous regional elections in 2020, the Constitutional Court has received 136 applications for dispute over results of the Regional Head Election. Applications for complete dispute over local election results will be registered on January 18 , 2021 and will be heard on January 26, 2021. In terms of numbers, the cases has increased compared to disputed applications for the results of the 2017 and 2018 Regional Head Election results, which were only 60 and 72 cases respectively.

According to Zoelva [3], various post-conflict local election problems show there are still many democratic agendas that we have to solve, both in terms of regulations, institutions, and law enforcement. At the present moment, we are at a point where ethical morality and the democratic process are still far from expectations. In such conditions, law, especially law enforcement institutions, becomes the foundation of hopes for saving democracy. This is in line with Fadjar [4] who stated that the role of the Constitutional Court in overcoming problems that arise in the implementation of the General Election at a certain stage received a positive response. Through its decisions, the Constitutional Court has responded to the problems of the Regional Head Election beyond the rigidity of procedural law by means of extensive interpretations. In this sense, as guardians of democracy, The Constitutional Court is obliged to ensure that the implementation of the Regional Head Election does not violate the principles of the constitution, namely an overflow and fair election. However, that does not mean that the Constitutional Court's legal steps did not receive a negative response, because it was considered to have ignored the law, and even expanded its own authority [4].

From the mandate for the establishment of a 'special judicial body' as well as the practice of resolving disputes over the results of the Regional Head Election by the Constitutional Court, there are still several legal problems related to conflict of norms and legal incompleteness which still feels obstructed. Article 157 Paragraph (1) of the Law regulates: "Election result dispute cases are examined and tried by a special judicial body". The Explanatory Section of this article only states "Self-explanatory". The 'explanation' section should be an 'official interpretation' (authentic) of the legislators who can help determine the purpose or background of the formation of these laws and regulations [5]. From this article, it is not clear about the form, institutionalization and jurisdiction of the agency's authority.

In connection with the election dispute resolution institutions in Indonesia, there have been several previous studies that have examined this issue.

From previous research, in addition to some similarities, there are also differences with this study, especially differences in perspective. This research is more complete, comprehensive, and up-to-date in examining the dynamics of the arrangement of dispute resolution institutions on the results of the regional elections in Indonesia for the 20052020 period. The different points of view also have implications for the analysis knife used so that the findings, conclusions and suggestions are relatively different from previous studies, as well as being complementary to previous studies.

The mandate of the law to form a "special judicial body" became a new hope, after the Constitutional Court issued Decision Number 97 / PUU-XI / 2013 which annulled the authority of the Constitutional Court to resolve disputes over the election results. In the course of resolving Election and Regional Head Election disputes in Indonesia, it has shown dynamic practices. The shifts in institutions authorized to settle disputes over the results of the Regional Head Election, at least indicate the unclear direction of the legal politics of dispute resolution over the results of the Regional Head Election in Indonesia. this does not guarantee justice and creates legal uncertainty, which is ideally part of the 15 elements of democratic election standards.

From the discussion above, the researcher proposes a research theme with the formulation of the problem "What are the dynamics of the arrangement of dispute resolution institutions on the results of the regional elections in Indonesia for the 2005-2020 period" which aims to find the ideal model for the Regional Head Election judiciary in Indonesia.

\section{METHODS}

This research is a type of juridical normative research, to study the application of norms or legal norms that are applied in positive law or laws that are still in force and have the power to bind legal subjects [6]. This type of normative law research in this study is to answer questions from the formulation of problems that have been raised using several 
approaches commonly used in legal research, namely the statute approach, conceptual approach, case approach, and historical comparative approach [7]. The technique of collecting legal materials as data used in this research is literature study using content analysis. According to Kriekhoff, in principle, content analysis is associated with secondary data or document studies and normative legal research or legal research also refers to the same data [8]. Analysis of legal materials is carried out by systematizing written legal materials. Systematization means classifying these legal materials to facilitate analysis and construction work [9]. The legal material obtained is then discussed, analyzed, and classified into certain groups to then be analyzed into information. Analysis of legal materials is carried out by systematizing written legal materials. Systematization means classifying these legal materials to facilitate analysis and construction work [9]. The legal material obtained is then discussed, analyzed, and classified into certain groups for later analysis into information. Analysis of legal materials is carried out by systematizing written legal materials. Systematization means classifying these legal materials to facilitate analysis and construction work [9]. The legal material obtained is then discussed, analyzed, and classified into certain groups to then be analyzed into information.

\section{RESULTS AND DISCUSSION}

The existence of a special judicial body authorized to adjudicate election disputes is part of the characteristics of the rule of law. The essence of a rule of law is the sovereignty or rule of law over humans. The rule of law emphasizes that everyone, regardless of their position and status in society, is under the law. For citizens, law includes both in a prescriptive sense that determines behavior which must be lawful - and in a protective sense towards citizens, in the form of demands against the government to act according to the law. The rule of law implies the entire constitution, and in one respect, all constitutional law with respect to the rule of law [10].

Meanwhile, the existence of a judicial body under the authority of an independent judiciary, impartial (impartial) is a feature of the rule of law. Article 1 of Law Number 4 of 2004 expressly regulates: "Judicial power is the power of an independent state to administer justice in order to uphold law and justice based on Pancasila, for the sake of the implementation of the State of Law of the Republic of Indonesia". A special court that is projected as a court for election disputes cannot be separated from the existence of judicial power.

In practice, every country has a branch of judicial power / 'the judiciary'. The main and first function of the branch of judicial power is to decide disputes between individuals and individuals, individuals and communities, even individuals or society and the state. The second function is to make a policy or policy [11]. Another function is to monitor government actions. The concretization of the functions of judicial power positions is carried out by judges who are equipped with various rights and obligations [12].

The existence of an independent and impartial judiciary is closely related to the adage that one of the keys needed to build a state system capable of realizing the ideals of justice lies in the issue of the quality of judicial power which requires serious attention in accordance with the demands of today's post-modern developments. . The principle of judicial independence is a universal principle that is adhered to and adheres to in every modern country. There is no country that can be called a democracy without an independent judicial power [13].

While the phrase for election disputes is viewed etymologically, it can be seen from the term dispute, which is an implication of the emergence of problems that arise in direct regional elections. Electoral dispute, namely "any complaint, challenge, claim or contest relating to any stage of the electoral process"[14]. From this understanding, the coverage of electoral dispute is basically broad and covers all stages of the Regional Head Election.

There are several Regional Head Election's disputes known in Indonesia, including the institutions authorized to try them. In practice, Regional Head Election disputes resolution could be divided into types of violations, disputes, criminal acts, and disputes over results, as can be seen in the following table.

\section{TABLE II. TYPES OF DISPUTES AND SETTLEMENT} INSTITUTIONS

\begin{tabular}{|l|l|l|l|}
\hline No. & Type of Dispute & $\begin{array}{l}\text { Settlement / Judiciary } \\
\text { Institution }\end{array}$ \\
\hline 1. & $\begin{array}{l}\text { Code of Conduct } \\
\text { Violation }\end{array}$ & $\begin{array}{l}\text { Election Organizer Honorary } \\
\text { Council (DKPP). }\end{array}$ \\
\hline 2. & Administrative Offenses & $\begin{array}{l}\text { Provincial/ Regency/ Municipal's } \\
\text { Election Supervisory Agency } \\
\text { (Indonesia: Bawaslu) }\end{array}$ \\
\hline 3. & Election Disputes & $\begin{array}{l}\text { Provincial/ Regency/ Municipal's } \\
\text { Election Supervisory Agency } \\
\text { (Indonesia: Bawaslu) }\end{array}$ \\
\hline 4. & Election Crime & & $\begin{array}{l}\text { District Court. } \\
\text { Administrative Court. }\end{array}$ \\
\hline 5. & TUN dispute & $\begin{array}{l}\text { Special Judicial Bodies, but it } \\
\text { was still implemented by the } \\
\text { Constitutional Court until the } \\
\text { establishment of a special judicial } \\
\text { body. }\end{array}$ \\
\hline 6. & Election Result Dispute & \\
\hline
\end{tabular}

From this it can be seen that the institutional arrangements for the settlement of local election disputes in Indonesia are scattered across several institutions which have resulted in ineffective settlement patterns. This is of course contradicting the principles of effective and efficient Regional Head Election administration. So, the formation of a special judicial body as mandated by Article 157 of Law Number 10 of 2016 is an empirical fact of the need to punish the community for the realization of legal certainty and justice in the implementation of General or Regional Head Election.

In addition, the handling of cases of violations and settlement of dispute cases tends to be prolonged and convoluted ignoring the principles of efficiency and effectiveness in the enforcement of election law, even though elections require a quick resolution to avoid potential loss of the rights of voters and election participants and prevent disruption government. This not only shows the unclear political direction of the institution for resolving disputes over the election / regional election results, but also leaves uncertainty which sometimes does not guarantee legal certainty for justice seekers. 
The special Regional Head Election court is actually one of the most important components in the principles of election hearing, one of which is legal certainty. In the context of legal certainty, it is that the election organizers, election supervisors, election observers and election participants receive well from the process stages, programs and time schedules for organizing the election. If there are parties who are not satisfied with the work provided by the KPU as an election organizer, they can file a dispute at the Special Election Court. The impact that can be seen significantly is that the Regional Head Election Court is to provide legal space to parties who are disadvantaged in the implementation of the Election to obtain legal certainty in the life of a democratic country [15].

Focusing on adjudicating disputes over the results of the Regional Head Election, Indonesia's judicial-administrative practice from 2005 to date presents a dynamic and interesting process from time to time. This can be observed:

1. First, mandated by Law Number 32 of 2004, the Supreme Court (MA) adjudicates disputes over the results of the election for the Governor, for disputes over the results of the election of the Regent / Mayor at the High Court, the Supreme Court's authority takes place between 2005-2008.

2. Second, issued Law Number 22 Year 2007 which classifies Regional Head Election into the Election regime. This is an entry point for the Constitutional Court (MK) to try regional election results disputes.

3. Third, the issuance of Law Number 12 Year 2008, which regulates the transfer of dispute settlement results from the Supreme Court to the Constitutional Court. Since 2008, the Constitutional Court has tried disputes over the results of the local elections.

4. Fourth, in 2014 the Constitutional Court Decision Number 97 / PUU-XI / 2013 was issued which annulled the Constitutional Court's authority to resolve disputes over the results of the regional elections.

5. Fifth, the issuance of Law Number 22 of 2014 which regulates Regional Head Election through DPRD, settlement of Election violations and disputes by the General Court, by delegating authority to four High Courts appointed by the Supreme Court.

6. Sixth, the Perppu No. 1/2014 appeared, disputes over the election results were submitted to the High Court appointed by the Supreme Court, with cassation as the last legal remedy in the Supreme Court.

7. Seventh, present Law Number 8 of 2015 (in conjunction with Law Number 10 of 2016), which regulates disputes over Election results that are tried by a special judicial body.

In tabular form, this can be seen in the Table III.

TABLE III. THE DYNAMICS OF THE AUTHORITY TO ADJUDICATE DISPUTES OVER THE RESULTS OF THE REGIONAL HEAD ELECTION ON 2005-2020

\begin{tabular}{|l|l|l|l|}
\hline No. & $\begin{array}{l}\text { Laws and } \\
\text { Regulations in } \\
\text { Indonesia }\end{array}$ & Judiciary Institution & $\begin{array}{l}\text { Authority } \\
\text { Validity } \\
\text { Period }\end{array}$ \\
\hline 1. & UU No. 32/2004 & a) The Supreme & $2005-$ \\
\hline
\end{tabular}

\begin{tabular}{|c|c|c|c|}
\hline & & $\begin{array}{l}\text { Court adjudicates the } \\
\text { dispute over the results } \\
\text { of the Governor } \\
\text { Election; } \\
\text { b) The High Court } \\
\text { hears disputes over the } \\
\text { results of the Regent / } \\
\text { Mayor election. }\end{array}$ & 2008 \\
\hline 2. & UU No.22 / 2007 & $\begin{array}{l}\text { Regional Head } \\
\text { Election into the } \\
\text { Election regime, the } \\
\text { Constitutional Court } \\
\text { adjudicates the dispute } \\
\text { over the results of the } \\
\text { Regional Head } \\
\text { Election. }\end{array}$ & $\begin{array}{l}\text { From } \\
2008- \\
2014\end{array}$ \\
\hline 3. & UU No.12 / 2008 & $\begin{array}{l}\text { The Constitutional } \\
\text { Court of the Republic } \\
\text { of Indonesia }\end{array}$ & $\begin{array}{l}\text { From } \\
2008- \\
2014\end{array}$ \\
\hline 4. & $\begin{array}{l}\text { The } \\
\text { Constitutional } \\
\text { Court Decision } \\
\text { No. } 97 \text { / PUU-XI } \\
\text { / } 2013\end{array}$ & $\begin{array}{l}\text { Overturning the } \\
\text { Constitutional Court's } \\
\text { authority to resolve } \\
\text { disputes over the } \\
\text { election results. }\end{array}$ & 2014 \\
\hline 5. & $\begin{array}{l}\text { UU no. } 22 \text { of } \\
2014\end{array}$ & $\begin{array}{l}\text { Regional Head } \\
\text { Election through } \\
\text { DPRD, settlement of } \\
\text { election violations and } \\
\text { disputes by the General } \\
\text { Court, by delegating } \\
\text { authority to four High } \\
\text { Courts appointed by } \\
\text { the Supreme Court }\end{array}$ & $\begin{array}{l}2014 \\
\text { (however, } \\
\text { it was not } \\
\text { realized). }\end{array}$ \\
\hline 6. & $\begin{array}{l}\text { Perppu No. } 1 \text { of } \\
2014\end{array}$ & $\begin{array}{l}\text { High Court appointed } \\
\text { by the Supreme Court, } \\
\text { with cassation as the } \\
\text { last remedy at the } \\
\text { Supreme Court. }\end{array}$ & $\begin{array}{l}2014 \\
\text { (however, } \\
\text { it was not } \\
\text { realized). }\end{array}$ \\
\hline 7. & $\begin{array}{l}\text { UU no. 8/2015 (in } \\
\text { conjunction with } \\
\text { Law Number } 10 \\
\text { of 2016), }\end{array}$ & $\begin{array}{l}\text { Special Judicial Bodies } \\
\text { however, disputes over } \\
\text { the election results } \\
\text { were tried by the } \\
\text { Constitutional Court } \\
\text { until the establishment } \\
\text { of a special judicial } \\
\text { body. }\end{array}$ & $\begin{array}{l}\text { Since } \\
2008- \\
\text { until now. }\end{array}$ \\
\hline
\end{tabular}

In the enforcement of election law, there are various alternative options for enforcement agencies (many rooms to justice), namely two institutions that are bifurcation systems, namely having two different and separate judicial power institutions, where the Supreme Court holds judicial power (ordinary court) in conventional cases, while The Constitutional Court holds judicial power in constitutional cases - the constitutional court [16].

To refer Article 1 Number 8 Law Number 48 Year 2009, "Special Court is a court that has the authority to examine, hear and decide certain cases which can only be formed in one of the judicial bodies under the Supreme Court as regulated in the Law". Since the era of the 1970s, ideas for reform emerged and the most prominent of which was to form a special court, which was separate from the existing general justice system. Independence and specificity are the keys to reforming the world of justice [17].

In Indonesia, the types and forms of judicial institutions in practice have indeed developed widely and are very diverse. There are special judicial bodies developed within the general court, such as the Corruption Crime Court (Indonesia: Pengadilan Tipikor), the Human Rights Court (Indonesia: Pengadilan HAM), the Juvenile Court, the Fishery Court, and the Commercial Court. There are also 
special courts within the Administrative Court, such as the Tax Court. In fact, new ideas have emerged to form judicial bodies that specifically handle separate development fields with good intentions to provide better guarantees in the effort to fulfill a sense of justice for the community [13].

The establishment of a special independent judiciary body in handling disputes over the results of the Regional Head Election is an important matter to be realized immediately to strengthen the existence of Regional Head Election. So far, whether or not it is important to establish a special court to resolve election and regional election disputes is still a matter of debate. One of the parameters of a democratic election or regional head election is a system of law enforcement and a fair and timely election dispute resolution [18]. Another thing that must be underlined is that this special court can only be established within one of the judicial bodies under the Supreme Court. Referring to Law Number 48 of 2009 concerning Judicial Power,

However, until now, during the simultaneous Regional Head Election implementation process in 2020, five years after the mandate for the establishment of a special Regional Head Election judiciary body, discussions regarding the special judiciary have yet to find a bright spot and even tend to fade. Even in the house of representative (Indonesia: DPR) as a drafting agency for regulations, this issue is not a concern and is not even something that is necessary and urgent to be concretized. Even the DPR is currently drafting two Election Codification Bills which negate the mandate of establishing a special Regional Head Election judiciary body. It seems that the DPR is satisfied with the existence of the Constitutional Court as the body with the authority to resolve Regional Head Election disputes, and denies this temporary authority. This can be interpreted that the formation of the Regional Head Election Special Judiciary Body has not find a clear direction.

Renewal of legal instruments regarding the special form of justice in cases of dispute over the results of the Regional Head Election must be implemented immediately to increase the value of democracy, not only for political interests and assisted by democratic efforts and to create Regional Head Election that provides justice and legal certainty. Hence, the jurisdiction of the special judiciary body for resolving election results must be expanded not only to handle disputes over results but also to handle other matters related to the Regional Head Election process itself. Beyond this, the author argues that the formation of this special judicial body must later expand its authority not only to handle disputes over the results of the Regional Head Election, but also the election process, administrative disputes, and election crimes [19].

The special Election Court is actually one of the most important components in the principles of election hearing, including legal certainty. In the context of legal certainty, it is that the election organizers, election supervisors, election observers and election participants receive well from the process stages, programs and time schedules for organizing the election. If there are parties who are not satisfied with the results of the work provided by the General Election Commission (KPU) as the organizer of the General and Regional Head Elections, they can file a dispute at the Special Court. The impact that can be seen significantly is that this Special Court provides legal space for parties who are disadvantaged in the implementation of the election to obtain legal certainty in the life of a democratic country [15].

From this argument, later on, dispute resolution over Regional Head Election results will be handled by a Special Court established by the Supreme Court, with reference to the competence (authority) of a court body to adjudicate a case that can be distinguished by relative competence and absolute competence. Relative competence is related to the court's authority to adjudicate a case in accordance with its jurisdiction. Meanwhile, absolute competence is the court's authority to adjudicate a case according to the object, material or subject matter of the dispute.

In the context of this article, the authors propose the option of forming a special judicial body in the PTUN environment. Regarding this alternative, it is important to pay attention to the views of Mawardi, a PTUN judge, who stated that the choice of institutions for handling disputes over the election results would be better if it was carried out through a special judicial body within PTUN which was based on several arguments, among others, that the determination of the results of the Regional Head Elections is a result of state administration, in which the KPU is a State Administrative Officer (TUN Official). In addition, Mawardi stated, one of the structural designs for the implementation of post-conflict local elections that can encourage effective and efficient enforcement of post-conflict local election administration law is the existence of a special court to handle and resolve disputes and violations in the postconflict local elections. In addition, Mawardi considered that the PTUN burden was still relatively light. The number of cases that are submitted and handled by the PTUN is relatively small when compared to other court institutions. Every year there are only 2,000 cases that go to the PTUN, even though it is dominated by land dispute cases [20].

This view is supported by the opinion that in the context of HTN / HAN, the KPU is a State Administration Officer (TUN Official) who carries out government (executive) functions in the General and Regional Head Elections sector. Any decision or determination made by the KPU has the consequence that it can be challenged by the party who feels aggrieved by the issuance of the KPU decision or determination. This condition is recognized by legislators because the potential for clashes, conflicts or legal disputes in the process and stages is always there. Therefore, lawmakers should aware that the conflicts or disputes that occur in the process of implementing the regulation might be resolved [21].

\section{CONCLUSION}

As a conclusion, the author proposes two institutional options for Regional Head Election dispute resolution: (a) establishing a Special Judiciary Body within the Civil Court of Justice which is domiciled in each provincial capital to adjudicate and decide on election disputes, with other expanded powers in the form of adjudicating Regional Head Election crimes as well as examining and adjudicating election, regional election, administrative process, and election disputes; or (b) defining the authority of the Constitutional Court to adjudicate disputes over the results of the Regional Head Election (in addition to the PHPU) 
without any differentiation between the General Election and the Regional Head Election.

\section{REFERENCES}

[1] S. Suhartono, "Konstitusionalitas badan peradilan khusus dan mk dalam penyelesaian sengketa hasil pilkada langsung (justice constitutionality of specialized judiciary and constitutional court in coping with the disputes on direct election results)", J. Konstitusi, Vol. 12, No. 3, September 2015.

[2] Budimansyah dan Hendrik, "Tinjauan terhadap kewenangan mahkamah konstitusi dalam memutus sengketa pemilihan kepala daerah (pilkada), J. SELISIK - Vol. 4, No. 6, Februari 2018.

[3] H. Zoelva, "Problematika penyelesaian sengketa hasil pemilukada oleh mahkamah konstitusi”, J. Konstitusi, Vol. 10, No. 3, September 2013.

[4] A. M. Fadjar, Pemilu, Perselisihan Hasil Pemilu, Dan Demokrasi: Membangun Pemilu Legislatif, Presiden, Dan Kepala Daerah Dan Penyelesaian Perselisihan Hasil Pemilu Secara Demokratis, Malang: Setara Press, 2013.

[5] M. F. Indrati S, Ilmu Perundang-Undangan 2: Proses dan Teknik Pembentukannya, Yogyakarta (Kanisius), 2007.

[6] J. Ibrahim, Teori dan Metodologi Penelitian Hukum Normatif, Malang:Bayumedia Publishing, 2006.

[7] P. M. Marzuki, Penelitian Hukum, Jakarta: Kencana Prenada Media Group, 2011.

[8] V. J. L. Kriekhoff, "Analisis konten dalam penelitian hukum: suatu telaah awal, era hukum", J. Ilmiah Ilmu Hukum, Fakultas Hukum Universitas Tarumanagara, No. 6, Th.2, 1995.

[9] S.Soekanto dan S. Mamudji, Penelitian Hukum Normatif, Jakarta: Raja Grafindo Persada, 2001.

[10] Barnett, Hilaire, Constitutional \& Administrative Law - Fourth edition first published, London UK: Cavendish Publishing Limited, 2002.

[11] Murphy, Walter, Courts, Judges \& Politics, An Introduction to the Judicial Process, Sixth Edition, Boston: McGraw Hill, 2005.
[12] S. D. Harjati, Politik Hukum Kekuasaan Kehakiman, dalam Imran (Peny/Ed), Meluruskan Arah Manajemen Kekuasaan Kehakiman, Jakarta (KYRI), 2018.

[13] J. Asshiddiqie, Pengadilan Khusus, dalam Hermansyah, dkk (peny/ed) Putih Hitam Pengadilan Khusus, Cet. Pertama, Jakarta (KYRI), 2013.

[14] International IDEA, International Electoral Standards, Guidelines for Reviewing the Legal Frameworkof Elections, Stockholm (International IDEA), 2002.

[15] W. Susetyo, Laporan Akhir Pengkajian Hukum Tentang Tinjauan Terhadap Efisiensi Pelaksanaan Pemilu Di Indonesia, (Jakarta, BPHN Kementerian Hukum Dan HAM RI, 2015.

[16] A. Riewanto, Kepastian Hukum Dan Tumpang Tindih Putusan Antar Lembaga Peradilan Dalam Perkara Pemilu, in Ahsanul Minan (Ed) Serial Evaluasi Penyelenggaraan Pemilu Serentak 2019 Perihal Penegakan Hukum Pemilu, Jakarta, (Bawaslu), 2019.

[17] Bedner, Adriaan, "Rebuilding the judiciary in indonesia: the special courts strategy", J. Yuridika Vol. 23 No. 3, September-Desember 2008.

[18] R. Rosanti, "Masa depan pemilihan kepala daerah pasca putusan mahkamah konstitusi nomor 55/PUU-XVII/2019”, JISPO Jurnal Ilmu Sosial dan Ilmu Politik, Vol. 10, No. 1, 2020.

[19] A. Elcaputera, "Kedudukan badan peradilan khusus perselisihan hasil pilkada berdasarkan undang-undang dasar negara republik indonesia 1945", J. Hukum Sehasen Vol.2 No.1, 2018.

[20] I. Mawardi, Dinamika Sengketa Hukum Administrasi Di Pemilukada: Mewujudkan Electoral Justice Dalam Kerangka Negara Hukum Demokratis, Yogyakarta: Rangkang Education \& JPPR, 2014.

[21] H. Munte, "Penyelesaian sengketa administrasi pemilihan kepala daerah berdasarkan undang-undang nomor 8 tahun 2015 tentang pemilihan gubernur, bupati dan walikota (studi putusan sengketa administrasi pemilihan walikota dan wakil walikota di panwas kota pematangsiantar tahun 2015”, USU Law Journal, Vol.5.No.1, 2017. 